\title{
GENEALOGIES, SEED AND THE COMPOSITIONAL UNITY OF GENESIS
}

\author{
T.D. Alexander
}

\section{Summary}

Most studies on Genesis tend to focus on the disparate nature of the material which has been used in its composition. It is argued here that the entire book has been carefully composed to focus on a unique family line. The members of this line of 'seed' enjoyed a special relationship with God which resulted in the establishment of two eternal covenants, the first with Noah and the second with Abraham. At the heart of this latter covenant was the promise that God's blessing would be mediated to all the nations of the earth through the 'seed' of Abraham. While the book of Genesis draws attention to the initial stages of the fulfilment of this promise, its ultimate fulfilment is linked to a royal dynasty associated with the descendants of Judah.

\section{Introduction}

A common feature of much biblical interpretation has been the fragmentation of the text; that is, the contents of a book are divided into small sections which are often interpreted in isolation from one another. ${ }^{1}$ The present division of the biblical books into chapters and verses encourages such an approach, and this is reflected at a popular level in the use of selected passages or texts in sermons or Bible studies. The commonly accepted style of commentaries, by which a book is examined chapter by chapter and verse by verse, also promotes a fragmented view of the text. While it is important to discover the anatomy of a biblical book by dissection, it is equally important to see how the component parts relate to each other. It is at this level that scholarship has been least successful, especially regarding the narrative sections of the Old Testament. To use a popular metaphor, biblical scholars often fail to see the wood for the trees.

\footnotetext{
${ }^{1}$ This is nothing new. The biblical commentaries from Qumran bear witness to the fact that even before AD 68 it was not uncommon for interpreters to divide up a passage into very short sections which were sometimes interpreted in isolation from the rest of the text. See M.P. Horgan, Pesharim: Qumran Interpretations of Biblical Books (Washington, The Catholic Biblical Association of America 1979).
} 
As regards the book of Genesis, modern critical methods have increased, rather than lessened, this tendency to fragment the text. Scholarly endeavours to discover the sources underlying Genesis have resulted in apparently unified narratives being viewed as composite. Interest in the final form of the text has given way to a detailed scrutiny of the component parts which are believed to underlie it. Many commentators excel at being able to reduce Genesis to various documents and/or editorial strands, without adequately appreciating that in the process they do not shed much, if any, light on the received form of the text. ${ }^{2}$

The application of form criticism to Genesis has added further to the fragmentation of the text. In the wake of Gunkel's analysis of Genesis, biblical scholars have generally viewed the book as a collection of once independent pericopes. Not surprisingly, this has created the impression that individual episodes may be understood adequately without considering their relationship to the many other episodes which comprise the rest of the book. Yet again attention is diverted away from the received form of the text. ${ }^{3}$ Not surprisingly, scholars have been influenced in their interpretation of Genesis by the manner in which they perceive it to have been composed. 4

2This is especially true of the massive commentary of C. Westermann, Genesis (ET, 3 vols.; London, SPCK 1984-1987).

${ }^{3}$ Several recent studies have highlighted the failure of scholars to demonstrate that the episodes which now comprise Genesis once enjoyed an independent existence; $c f$. R.N. Whybray, The Making of the Pentateuch (JSOTS 53; Sheffield, JSOT Press 1987) 133-219; P.G. Kirkpatrick, The Old Testament and Folklore Study (JSOTS 62; Sheffield, JSOT Press 1988). S.M. Warner, 'Primitive Saga Men', VT 29 (1979) 335, comments: 'At present we see no reason to assume that the narratives of Genesis bear any close resemblance to orally transmitted data at all. If biblical scholars wish to argue such a thesis, they must develop new criteria with which to establish it.'

4For example, J.C.L. Gibson, Genesis, Vol. 1 (Edinburgh, Saint Andrew Press 1981) 1-2, comments: "The original "genius" of the book is the people of Israel itself. Or to be a little more exact, it is the unknown "bards" or professional "singers of tales" who during the Wilderness Wanderings and in the period of the Judges first gave literary shape to the memories and experiences and the hopes and fears of the newly born nation. The work of these "singers of tales" was entirely oral and has disappeared, but if any one deserves the title of Genesis' "author", it is they.' 
These negative comments about the influence of source and form criticism upon our appreciation of the book of Genesis have no direct bearing on the validity of the results attained by these methods. However, source and form critical studies must be developed in the light of a full and proper investigation of the text as now received. Unfortunately, this is too rarely the case. It is, therefore, hardly unexpected that the results so far attained by these methods appear to be less than satisfactory. 5

A neglected aspect of much discussion on Genesis has been the decisive role of the individual, be he (or she) author or editor, who gave the book its present form. Even if one grants that it is possible to identify the different sources, whether oral or literary, that were used in the composition of Genesis, this of itself is only part of the interpretive process. It is still necessary to understand how these different parts relate to each other. Why did the author/editor select and arrange the material to form the present text? What overall intention underlies the final composition of Genesis? In this regard it is perhaps helpful to compare Genesis to a collage made of different types of materials and colours. Merely to note the origin of the different parts or their particular features is insufficient. We need also to observe the way in which they interrelate and the effect which they produce as a whole.

\section{The line of 'seed' in Genesis}

For many readers Genesis appears to be a collection of unconnected stories interrupted here and there by apparently irrelevant genealogies. Yet the present text has been carefully shaped to highlight the importance of a family lineage which begins with Adam and is traced through to the sons of Jacob. This is highlighted by two distinctive literary features: (a) the תוֹלְדוֹת headings which introduce the different sections of the book, and (b) the repeated use of the Hebrew word זִ ('seed'). After examining these features we shall make some general

${ }^{5}$ For two recent studies which highlight the unsatisfactory nature of the source analysis of selected chapters of Genesis, see T.D. Alexander, 'The Hagar Traditions in Genesis xvi and xxi', in J.A. Emerton (ed.) Studies in the Pentateuch (VTS 41; Leiden, E.J. Brill 1990) 131-148; idem, 'Are the wife/sister incidents of Genesis literary compositional variants?', VT 42 (1992) 145-153. 
observations about the nature of the special lineage found in Genesis.

One of the most distinctive features of Genesis in its received form is the use of similar headings to introduce the narratives and genealogies which alternate throughout the book. These occur in $2: 4 ; 5: 1 ; 6: 9 ; 10: 1 ; 11: 10,27 ; 25: 12,19 ; 36: 1$, 9; 37:2.6 The common element in all of these headings is the Hebrew word silich is translated by a variety of terms in almost every modern version, the most common being: descendant(s); account; generations; history; list; record; roll; story. The word itself is associated with 'giving birth' and when linked to a person or object refers to that which a person or object produces.7 For example, the initial words of 11:27 could be translated, 'And these were born of Terah'.

תוֹרלדוֹת headings serve two functions. Firstly, they are like chapter headings in modern books. Some of them introduce major narrative sections, indicating a new stage in the development of the plot. These major sections deal mainly with the lives of Adam, Noah, Abraham, Jacob and Joseph, and they are introduced by the headings in $2: 4,86: 9,11: 27,25: 19$ and 37:2 respectively. The other תוֹלְדוֹת headings introduce either linear genealogies which list descendants who belong to the central family line $(5: 1 ; 11: 10)$, or segmented genealogies which provide details about the family members of some of the minor

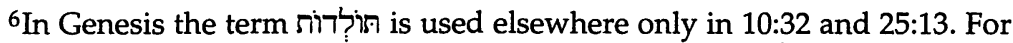
a brief discussion of how scholars have treated the תוֹלְרוֹת formula, see M.H. Wouldstra, 'The תוֹ תוֹדוֹת the Book of Genesis and Their Redemptive-historical Significance', CTJ 5 (1970) 184-189. For a detailed treatment of these headings which emphasises that they must be assigned to the final stage in the composition of Genesis, see F.M. Cross, Canaanite Myth and Hebrew Epic (Cambridge, Harvard University Press 1973) 301305.

${ }^{7}$ E. Fox, Genesis and Exodus: A New English Rendition (New York, Schocken Books 1991) translates תוֹלְדוֹ by the phrase 'the begettings of'.

${ }^{8}$ Although it is sometimes suggested that the heading in 2:4a must have originally stood before 1:1, J. Skinner, Genesis (Edinburgh, T. \& T. Clark 1910) $40-41$, rejects this possibility, observing that the phrase must describe that which is generated by the heavens and the earth, not the process by which they themselves are generated'; cf., Cross, op. cit., 302; B.S. Childs, Introduction to the Old Testament as Scripture (London, SCM Press 1979) 145-150; G.J. Wenham, Genesis 1-15 (Waco, Word 1987) 55-57. 
participants in Genesis $(10: 1 ; 25: 12 ; 36: 1,9) .{ }^{9}$ To ensure that the main line of descent in Genesis is clearly established, segmented genealogies are never used in relation to it; only linear genealogies are employed (5:1-32; 11:10-26).

Secondly, the תוֹלְרוֹת headings function like a zoomlens on a camera. They focus the reader's attention on a particular individual and his immediate children. This enables the author of Genesis to trace the fortunes of the main family line without having to follow in detail the lives of all other relatives. In this way Genesis highlights the lineage which, beginning with Adam, is traced through Adam's youngest son Seth to Noah, the father of Shem, Ham and Japheth. The next stage of the line takes us from Shem to Terah, the father of Abraham, Nahor and Haran. We then move from Abraham to Isaac, from Isaac to Jacob, and, finally, to Jacob's twelve sons.

Closely linked to the genealogical structure of Genesis is the frequent use of the Hebrew word 2 ? which is perhaps best translated as 'seed'.10 This is a Leitwort or keyword in Genesis, occurring 59 times compared to 170 times in the rest of

9The distinction between 'linear' and 'segmented' genealogies is discussed by R.R. Wilson, Genealogy and History in the Biblical World (New Haven, Yale University Press 1977) 9. A linear genealogy takes the form: A gave birth to $B, B$ gave birth to $C, C$ gave birth to $D$. A segmented genealogy takes the form: A gave birth to B, C and D; B gave birth to E, F and G; C gave birth to $H, I$ and J; D gave birth to $K, L$ and $M$. The difference between the two forms may be illustrated as follows:

\section{Linear:}

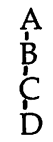

Segmented:

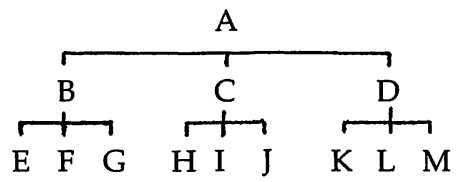

10Most modern versions disguise the repeated use of in the Hebrew text of Genesis by translating it using a variety of terms: e.g., 'descendants', 'offspring', 'seed', 'children', 'family', 'grain', 'semen', 'line', 'people'. 
the Old Testament. ${ }^{11}$ Several factors are worth noting briefly about the use of the term 'seed' in Genesis. (a) זֵרע can be either singular or plural; it may denote a single seed or many seeds. An example of the former comes in 21:13 where Ishmael is described as Abraham's 'seed'. On the other hand, in 28:14 זרע refers to the descendants of Jacob 'who will be like the dust of the earth'. (b) זֵרע normally denotes an individual's natural child or children. When Eve gives birth to Seth she comments, 'God has granted me another child (seed) in place of Abel, since Cain killed him' (4:25). In 15:3 Abraham laments the fact that although his heir is Eliezer of Damascus, he is not of his own seed; this reflects the fact that as yet Abraham and Sarah have no child of their own. (c) ז ז conveys the idea that there is a close resemblance between the 'seed' and that which has produced it. This is highlighted at the outset in the comment that plants and trees were to produce seeds 'according to their various kinds' (1:11-12).12

When Genesis is viewed as a whole it is very apparent that the genealogical structure and the concept of 'seed' are closely linked in order to highlight a single, distinctive, family lineage (see Diagram A). Moreover, although Genesis concludes by noting that the total 'seed' of Jacob was reckoned as numbering seventy (46:6-27), within this group of seventy special attention is focused on the status given to the descendants of two of Jacob's sons, Joseph and Judah. As we shall observe below, although Joseph's younger son Ephraim receives the blessing of the first-born from his grandfather Jacob (48:1-22), it is to Judah and his descendants that the promise of kingship is given (49:8-12).

11These statistics exclude the one occurrence of the Aramaic word in Daniel 2:43. In Genesis זٓר comes in 1:11 (x2), 12 (x2), 29 (x2); 3:15 (x2); $4: 25 ; 7: 3 ; 8: 22 ; 9: 9 ; 12: 7 ; 13: 15,16(x 2) ; 15: 3,5,13,18 ; 16: 10 ; 17: 7(x 2), 8,9,10$, 12,$19 ; 19: 32,34 ; 21: 12,13 ; 22: 17(x 2), 18 ; 24: 7,60 ; 26: 3,4(x 3) ; 28: 4,13,14$ (x2); 32:12; 35:12; 38:8, 9 (x2); 46:6, 7; 47:19, 23, 24; 48:4, 11, 19.

12For modern readers familiar with the concept of genetics the importance of the comments about seed in 1:11-12 tends not to be appreciated. Yet, the emphasis given to 'seed' in these verses is significant for the whole book. 
Diagram A : The Main Family Lineage in Genesis ${ }^{13}$

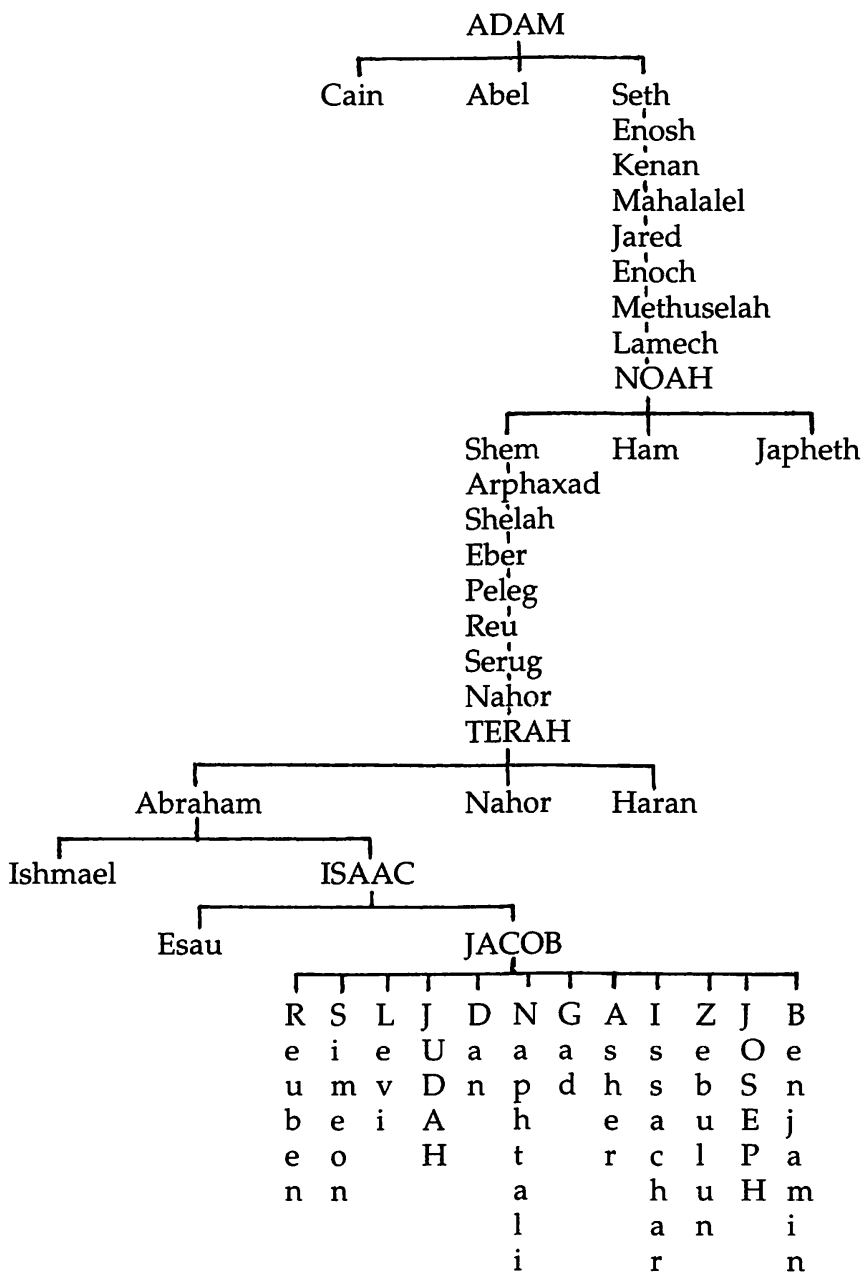

When one examines the nature of the main family lineage in Genesis, various features are noteworthy. First, the lineage is always traced through male descendants, and all are clearly

${ }^{13}$ Reproduced from T.D. Alexander, 'From Adam to Judah: the significance of the family tree in Genesis', EvQ. 61 (1989) 7. 
named.14 While it might have been expected that this line of 'seed' would continue through the eldest son, this is not so. In a number of instances a younger son is given priority over an older brother, and, interestingly, on each occasion the text of Genesis suggests why this occurs. For killing his brother Abel, Cain, the first-born, is passed over in favour of Seth, the thirdborn (4:1-25). Although Ishmael is Abraham's first-born son, he is excluded from the line of 'seed' because he is the son of Sarah's Egyptian maidservant Hagar (16:1-16; 17:18-21; 21:920). As the divinely intended 'seed' of Abraham, Isaac enjoys priority over his older brother Ishmael. Esau's secondary position to Jacob is divinely predicted prior to the birth of the twin boys (25:23), and the ensuing narrative appears to justify this choice by highlighting Esau's attitude towards his birthright, which he sells to Jacob for a pot of red stew (25:29$34)$, and by the fact that he displeases his parents by marrying two Hittite women (26:34-35).

A more complex situation exists regarding the twelve sons of Jacob, where both Judah, the fourth-born, and Joseph, the eleventh-born son, are privileged before older brothers. On the one hand, the blessing of the first-born is passed on by Jacob to Joseph's family when he blesses his two sons Manasseh and Ephraim. Remarkably, once again the younger son, Ephraim, receives the superior blessing (48:1-22). On the other hand, Jacob indicates that the royal line will be traced through Judah (49:8-12; cf. 1 Ch. 5:1-2). ${ }^{15}$ The Genesis narrative reveals that the eldest brothers, Reuben, Simeon and Levi, are

14Wilson, op. cit., 133-134, observes that in the ancient Near East there was a tendency to limit the maximum length of a written genealogy to ten generations, such as we have in Genesis chs. 5 and 11. Consequently, it is not uncommon to find Near Eastern genealogies being modified by the addition or omission of names. Examples of names being omitted are also found in biblical texts (e.g., compare 1 Ch. 6:3-14 and Ezra 7:1-5; cf. W.H. Green, 'Primeval Chronology' Bibliotheca Sacra, 47 [1890] 285-303). For this reason, it is doubtful if the genealogies in chs. 5 and 11 can be used with confidence to construct a chronology for the early chapters of Genesis.

15In Numbers 2:3 and 10:14 the tribe of Judah comes first in lists involving all the tribes ( $c f$. Jos. 15:1). The pre-eminence of the tribe of Judah may also be observed in the layout of the Israelite camp during the wilderness period. Judah was located on the east side, nearest to the entrance into the tabernacle. 
excluded from enjoying their father's foremost blessing due to their unrighteous actions $(35: 22 ; 34: 25-30)$.

Second, it is noteworthy that the central family line exists due to the gracious activity of God. As the outset Eve recognises this following the birth of Seth: 'She named him Seth, saying, "God has granted me another child (seed) in place of Abel, since Cain killed him"' (4:25). It is, however, in the lives of Abraham, Isaac and Jacob that we see most clearly God's role in sustaining the family line. In the account of Abraham's life, one of the first details recorded is that 'Sarai was barren; she had no children' (11:30). As the Abraham story unfolds, God reiterates on various occasions that Sarah will indeed bear a son $(17: 16-21 ; 18: 10-14)$, and this in spite of the fact that both Abraham and Sarah are well beyond the natural age of having children; Abraham is one-hundred years old $(17: 17 ; 21: 5)$ and Sarah ninety $(17: 17)$. When at last Sarah gives birth to Isaac, the text specifically states that this is due to divine intervention: 'Now the LORD was gracious to Sarah as he had said, and the LORD did for Sarah what he had promised' (21:1). A similar situation is recorded very briefly in 25:21 regarding Isaac and Rebekah: 'Isaac prayed to the LORD on behalf of his wife, because she was barren. The LORD answered his prayer, and his wife Rebekah became pregnant.' Remarkably, history repeats itself yet again in the case of Jacob, for his wife Rachel is also barren (29:31). When Rachel eventually gave birth to a child of her own, the narrative once more affirms God's part in this:

Then God remembered Rachel; he listened to her and opened her womb. She became pregnant and gave birth to a son and said, 'God has taken away my disgrace.' She named him Joseph, and said, 'May the LORD add to me another son' (30:22-24).

All of these examples highlight that God was actively responsible for the continuation of the family line.

Third, the Genesis narrative emphasises the existence of a special relationship between God and individual members of the main family line. We see this in a variety of ways. Sometimes it is highlighted by brief comments. For example, we read, 'Enoch walked with God; then he was no more, because God took him away' (5:24). The תוֹלְדוֹת heading of Noah is immediately followed by the statement, 'Noah was a righteous man, blameless among the people of his time, and he 
walked with God' (6:9). ${ }^{16}$ Elsewhere the presence of a special relationship is revealed in considerably more detail. This is so in the longer accounts concerning Noah, Abraham, Isaac, Jacob and Joseph. In the cases of Noah and Abraham, God not only reveals future plans but also establishes eternal covenants through both of them. Isaac and Jacob also experience revelations from God confirming, in particular, the promises which were previously made to Abraham. Although God never reveals himself directly to Joseph, he enables him to discern the future by interpreting dreams. Moreover, the entire account of Joseph's time in Egypt emphasises God's providential care of him.

While the members of the main family line enjoy God's favour and blessing, their faults and failures are never disguised. We see Noah becoming drunk (9:20-21), Abraham being less than fully truthful concerning his marriage to Sarah (12:10-13), and Jacob knowingly deceiving his father (27:1-40), 17 to mention a few of the more obvious short-comings. Nevertheless, in spite of such faults, the members of the family

${ }^{16}$ The Hebrew original of the comments in 5:22, 24 and 6:9 that Enoch and Noah 'walked with God' uses the Hitpa'el form of the verb הלכ ('walk'). The same form occurs elsewhere in Genesis in 3:8; 13:17; 17:1; 24:40; 48:15. Apart from 3:8, where God is the subject of the verb, and with the possible exception of 13:17, on all of these occasions the verb 'walk' denotes a special relationship with God. N.M. Sarna, Genesis (Philadelphia, Jewish Publication Society 1989) 123, comments: 'this expression seems originally to have been a technical term for absolute loyalty to a king.'

${ }^{17}$ While some readers may feel that by deceiving his father and stealing his brother's blessing Jacob acted immorally, various details in the narrative suggest that Jacob's actions are pardoned, at least in part, by the narrator. First, the narrative emphasises that Rebekah not only instigated the deception (27:5-10) but also stated that she would accept full responsibility should the deception be discovered (27:13). Second, the narrator appears critical of Isaac for allowing his appetite for wild game to influence his attitude towards Esau (25:28). Because of his love for Esau, Isaac seemingly ignored the implications of the divine statement made prior to the birth of the twin boys that Esau would be subservient to Jacob (25:23). Third, the concluding comments of chapter 26, that Esau's wives were a source of grief to Isaac and Rebekah (26:34-35), together with the earlier story of Esau selling his birthright for some stew (25:29-34), suggest that Esau was not worthy of the special paternal blessing. In the light of these factors, responsibility for Jacob's deception is shared by all the family members. 
line are viewed as more righteous than others. This is perhaps most evident in the case of Noah, who is introduced as 'a righteous man, blameless among the people of his time' (6:9) and who, with his family, was not condemned to destruction by the flood like all other human beings. Abraham's righteousness is highlighted in various ways. It is first mentioned specifically in 15:6 where the narrator comments, 'Abram believed the LORD, and he credited it to him as righteousness'. Later, the extent of Abraham's righteousness is revealed by his willingness to obey God and sacrifice his much loved son Isaac (22:1-19).

Although, in comparison to the other patriarchs, relatively little information is given about Isaac, the fact that he clearly enjoyed God's favour suggests that he too was viewed as righteous ( $c f .26: 12-13 ; 23-24$ ). Jacob's relationship with God develops over a long period of time, and although Genesis focuses initially on his deceptive behaviour (27:1-29), we see him eventually taking active steps to rid his household of foreign gods (35:1-5). Like Abraham and Isaac, Jacob too knows God's blessing. Furthermore, all three patriarchs actively worship God by building altars and offering sacrifices (12:7-8; $13: 18 ; 22: 9 ; 26: 25 ; 35: 1-7)$.

Fourth, as noted above, the concept of 'seed' implies a resemblance between the 'seed' and the one who has produced it. In the context of Genesis this suggests that sons will resemble their fathers. The most obvious example of this comes in the record of Isaac's stay in the region of Gerar (26:1-35). Here Isaac's behaviour mirrors closely that of his father. Like Abraham he pretends that his wife is his sister (26:1-11; cf. $12: 10-20 ; 20: 1-18)$, is involved in a dispute with the inhabitants of Gerar over the ownership of certain wells (26:17-25; cf. 21:22$34)$, and enters into a covenant with Abimelech (26:26-31; cf. 21:22-34). In a different way, Jacob's sons resemble him in that they too deceive their father $(27: 1-29 ; 37: 12-35)$. Significantly, those elder sons who are overlooked in favour of younger brothers, generally exhibit behaviour which is not in keeping with that expected of the line of 'seed'. For example, Reuben's affair with his father's concubine Bilhah (35:22; cf. 49:3-4) and the murderous actions of Simeon and Levi prevent them from receiving the blessing of the first-born from their father Jacob (34:1-31; cf. 49:5-7). 
Members of the main family line are not the only ones in Genesis to share common features; the same is true of others. Cain's murderous actions are repeated by his descendant Lamech (4:19-24). Similarly, listed among the descendants of Ham, who sinned against his father Noah, are the Canaanites (who include the inhabitants of Sodom and Gomorrah) and the Amorites (10:15-19), all of whom are viewed as worthy of divine punishment (cf. 13:13; 15:16; 19:1-29).

Fifth, the 'seed' of the main family lineage is frequently mentioned in the divine promises which are an important feature of the patriarchal stories. Three aspects of these promises deserve special notice. (a) God promises the land of Canaan to the 'seed' of Abraham. This is mentioned specifically when Abraham first arrives in Canaan, "To your seed I will give this land' (12:7), and repeated on various occasions to Abraham, Isaac and Jacob (13:15; 15:18; 17:8; 22:17; 26:3; 28:13; $35: 12 ; c f .24: 7 ; 24: 60 ; 28: 4 ; 48: 4)$. (b) It is frequently stressed that the 'seed' of Abraham will be very numerous. Three images are used to highlight the extent of the 'seed': the dust of the earth $(13: 16 ; 28: 14)$, the stars of the heavens $(15: 5: 22: 17 ; 26: 4)$ and the sand of the seashore $(22: 17 ; 32: 12)$. The fulfilment of the promise of numerous descendants, like that of land (cf. 15:1314), clearly lies beyond the book of Genesis, indicating that Genesis merely records the beginning of something which will only be completed later. (c) It is emphasised that through Abraham and his 'seed' all nations on earth will be blessed $(12: 3 ; 18: 18 ; 22: 18 ; 26: 4 ; 28: 14)$. Interestingly, within the patriarchal narratives the power to bless others is linked to those who receive from their father the blessing reserved for the first-born. While Ishmael and Isaac are both the 'seed' of Abraham, God indicates that the divine promises will be fulfilled through Isaac, not Ishmael. Similarly, although Esau and Jacob are both Isaac's 'seed', it is Jacob who receives God's blessing and mediates it to others. Of the twelve sons of Jacob, Joseph is singled out as the one through whom others are blessed. 18 Thus, although other 'seed' exist, the patriarchal

18In the case of Joseph, the text does not state explicitly that he received the blessing of the first-born from his father. However, it is clear that (a) he was the most favoured of all Jacob's sons and (b) that the blessing of the first-born was formally given by Jacob to Joseph's youngest son Ephraim (48:1-22). 
narratives associate the mediation of God's blessing with the son who receives the first-born blessing. This observation has important implications for the divine promise that, through the 'seed' of Abraham, God's blessing will come to the nations of the earth (22:18). 'Seed' in this context probably refers to a single descendant.

References to 'seed' are not restricted to the divine promises made to the patriarchs. Much earlier in Genesis the LORD draws attention to the fact that the 'seed' of the woman will overcome the 'seed' of the serpent (3:15). This reference to the 'seed' of the woman must be interpreted in the light of the rest of Genesis which focuses on a single line of seed.19 While the immediate context of ch. 3 permits the term ז? understood as a plural, it is note worthy that Eve later remarks concerning the birth of Seth: 'God has granted me another child (seed) in place of Abel, since Cain killed him' (4:25). Significantly, it is through Seth that Genesis traces the line of 'seed' which will overcome the 'seed' of the serpent.

Sixth, there are strong grounds for believing that the main line of descent in Genesis is viewed as a royal lineage. This possibility is implied by the divine promise made to Abraham that 'kings will come from you' (17:6), echoed in a similar statement concerning Sarah that 'kings of peoples will come from her' (17:16). Moreover, although Abraham is never directly designated a king, he is occasionally portrayed as enjoying the status of a king. We see this in his defeat of the eastern kings in chapter 14, in the desire of Abimelech, king of Gerar, to make a covenant with him (21:22-34), and, finally, in the title 'mighty prince' (literally, 'a prince of God') bestowed upon him by the Hittite inhabitants of Hebron (23:6).

While there are only a few allusions to kingship in chapters 25-36, these are nevertheless noteworthy. Isaac's special standing is reflected in Abimelech's wish to enter into a treaty with him (26:26-31), as he had previously done with Abraham. Jacob is promised, in a divine speech which echoes ch. 17, that 'kings will come from your body' (35:11). Finally, the brief comment in 36:31, 'These were the kings who reigned in Edom before any Israelite king reigned', indicates that

${ }^{19}$ See Alexander, 'From Adam to Judah', 15-18. 
whoever wrote this either anticipated or already knew of a royal dynasty within Israel.

The subject of kingship is prominent in the Joseph story. At the outset his brothers interpret Joseph's first dream to mean that he will be a king: 'Do you intend to reign over us? Will you actually rule us?' (37:8). His second dream reinforces this idea (37:9-11), and later we witness the fulfilment when Joseph rises from the obscurity of an Egyptian prison to hold the office of governor of Egypt, second only to Pharaoh (41:3943).

Although Joseph enjoys the spotlight in chapters 37-50, it is noteworthy that of the other sons of Jacob most attention is focused on Judah ( $c f .43: 8-9 ; 44: 16 ; 44: 18-34 ; 46: 28$ ). This is particularly so in chapter 38 where we have one of the more unusual episodes in the book of Genesis. The inclusion of this story can best be accounted for by noting that it focuses on Judah's reluctance, following the deaths of his sons Er and Onan, to allow Er's wife Tamar to marry Judah's third son Shelah in order to produce 'seed' and so maintain the family line. ${ }^{20}$ When Tamar eventually becomes pregnant by deceiving Judah, he is forced to acknowledge the righteousness of her actions (38:26). Significantly, the account concludes by recording the birth of Perez (and his twin brother Zerah) from whom the royal line of David is descended.21

${ }^{20}$ Although ch. 38 is generally viewed as an independent unit unrelated to the Joseph story, R. Alter (Commentary 60 [1975] 73-77]) highlights a number of important parallels between chs. 37 and 38. Significantly, he comments: "There is thematic justification for the connection since the tale of Judah and his offspring, like the whole Joseph story, and like the entire book of Genesis, is about the reversal of the iron law of primogeniture, about the election through some devious twist of destiny of a younger son to carry on the line. There is, one might add, genealogical irony in the insertion of this material at this point of the story, for while Joseph, next to the youngest of the sons, will eventually rule over his brothers in his own lifetime as splendidly as he has dreamed, it is Judah, the fourth-born, who will be the progenitor of the kings of Israel, as the end of Chapter 38 will remind us' (p. 74). It should also be noted that the survival of Judah's family, like that of all the other descendants of Jacob, is dependent on Joseph's presence in Egypt; this explains why the narrative devotes most space to recounting what happened to Joseph.

${ }^{21}$ The are interesting parallels between chapter 38 and the book of Ruth which concludes by giving the genealogy of king David beginning with Perez the son of Tamar (Ru. 4:18-22). Although Tamar and Ruth are non- 
Judah's importance is further indicated by the special blessing which he receives from his father in 49:8-12. Without considering every aspect of this blessing, the following points are worth noting. First, when compared with the other blessings pronounced by Jacob upon his sons, the length and content of Judah's blessing clearly suggests that he enjoyed a special relationship with his father. Only Joseph receives a comparable blessing. Second, Jacob states that Judah and his descendants will exercise leadership over his other brothers and their descendants (49:8). We see this especially in the comment that 'Your father's sons will bow down to you' (49:8) and in the reference to the sceptre and ruler's staff not departing from Judah (49:10). ${ }^{22}$ Third, Jacob anticipates that eventually there will come in the royal line of Judah one to whom the nations will submit in obedience (49:10) and whose reign will be marked by prosperity and abundance (49:11). Such comments would clearly have been very important for the royal line of David, justifying its claim to rule over the whole of Israel. ${ }^{23}$

\section{Conclusion}

From this survey of Genesis it is apparent that the entire book highlights the existence of a unique line of 'seed' which will eventually become a royal dynasty. Members of this lineage enjoy a special relationship with God who actively provides

Israelites, they both play an active role in continuing the royal line. It is also interesting to observe that David names one of his daughters Tamar (2 Sam. 13:1).

22Westermann (Genesis 37-50, 230) argues, mainly on the basis of Judges 5:14, that the terms מֶוֹקָק (staff) refer to a 'commander's staff' and are not be to associated with the office of a king. However, the word שֶׁבט does on occasions clearly denote a king's sceptre (e.g., Ps. 45:7). ${ }^{23}$ Obvious parallels exist between the Abrahamic and Davidic covenants;cf. R.E. Clements, Abraham and David: Genesis XV and its Meaning for Israelite Tradition (London, SCM Press 1967). Given that David is the youngest of Jesse's sons, it is interesting to note that in Genesis the privilege of primogeniture is frequently overturned in favour of a younger son. For further links between Genesis and the biblical material concerning king David, see B. Mazar, 'The Historical Background of the Book of Genesis', Journal of Near Eastern Studies 28 (1969) 73-83; G.A. Rendsburg, The Redaction of Genesis (Winona Lake, Eisenbrauns 1986) 107120. 
and sustains each new generation. We are also informed that the 'seed' of this lineage, from Abraham onward, will become very numerous and possess the land of Canaan. Thus, Genesis focuses not only on the early ancestry of the David monarchy but also on the beginnings of the nation of Israel. In that the king and the nation are of the 'seed' of Abraham, they share a common origin, and, as recipients of the divine promises, a common destiny.

For a long time Genesis has been subjected almost exclusively to the approaches of source and form criticism. Yet, whatever the origin of the material comprising Genesis, the author/compiler has clearly integrated its apparently diverse contents to provide a literary work which exhibits much greater unity than is generally recognised or acknowledged. A thorough investigation reveals that there is hardly a passage in Genesis which does not relate in one way or another to the family line which lies at the heart of the book. This unique family line, therefore, is a crucial aspect of the interpretation of the book of Genesis. 